\section{Tenner, kropp og sjel}

\section{Björn Klinge}

\section{Munnen}

Tänder, kropp och själ. 114 s, ill. Stockholm: Karolinska Institutet University Press, 2010. Pris SEK 165

ISBN 978-91-85565-29-0

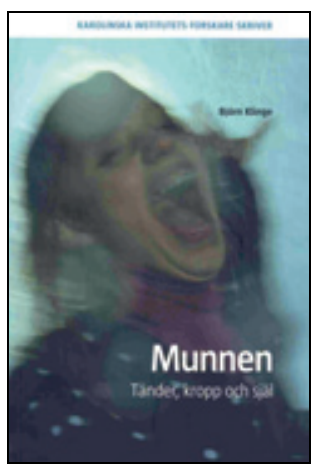

Boken er en del av en populærvitenskapelig bokserie skrevet av forskere fra Karolinska Institutet i Stockholm. Serien omhandler vanlige sykdommer, hva de skyldes, og hvordan de behandles. Björn Klinge er professor og overtannlege ved tannlegeutdanningen på Karolinska Institutet.

Forfatteren omtaler munnhulen både fra et biologisk, psykologisk og sosialt perspektiv. Ikke tilfeldig heter første kapittel Skam, skyld og tannløshet. Han beskriver munnhulens anatomi og fysiologi på en populærvitenskapelig måte som gir godt grunnlag for beskrivelser av de to vanligste sykdommene i munnen: karies og periodontitt.

Forfatteren er spesialist i periodonti, og en vesentlig del omhandler tanntap og muligheter for erstatning av tapte tenner. Moderne odontologi gir mulighet for avanserte løsninger med innsetting av tannimplantater i kjevebein og rekonstruksjon av tenner festet i implantatene. Disse behandlingsformene gir nye utfordringer til tannhelsepersonell, annet helsepersonell og ikke minst pasientene selv. Forfatteren gir en grei innføring i bakgrunn for, gjennomføring og vedlikehold av slike behandlingsløsninger.

Avslutningsvis konsentrerer forfatteren seg om betydningen av munnhulens funksjon og estetikk. Veletablerte sammenhenger, så vel som nyere og mer usikre teorier om samspill mellom tenner og tyggefunksjon, samt psykisk og fysisk helse, blir diskutert.

Boken er beregnet på interesserte pasienter, men kan meget godt leses av helsepersonell som vil øke eller repetere kunnskap innen odontologiske fagområder og fagutvikling. Illustrasjonene er mange og må fremheves som svært gode. Boken er kortfattet på lettlest svensk og vil bidra til å gi leseren grunnleggende kunnskap og forståelse for at munnhulen er en sentral og viktig kroppsdel som har vesentlig betydning for helsen.

$\AA$ miste tennene er ofte minst like utfordrende fysisk og psykisk som å miste andre kroppsdeler som fingre eller bryst. Per i dag er tannhelse økonomisk og organisatorisk atskilt fra alle andre medisinske fagområder. Det er en utfordring. I moderne helseperspektiv bør tannhelse inkluderes i forebygging og behandling av både psykiske og fysiske lidelser. Det krever økt kompetanse om munnhulen i alle medisinske fagmiljøer. Denne boken kan bidra til dette.

\section{Tiril Willumsen}

Institutt for klinisk odontologi

Universitetet i Oslo

\section{Viktig kunnskap gjenoppdaget}

\section{Eli Berg}

\section{Sammenhenger}

Om erfaring, sykdom og medisinsk praksis.

188 s. Oslo: Gyldendal Akademisk, 2010.

Pris NOK 345

ISBN 978-82-05-39900-6

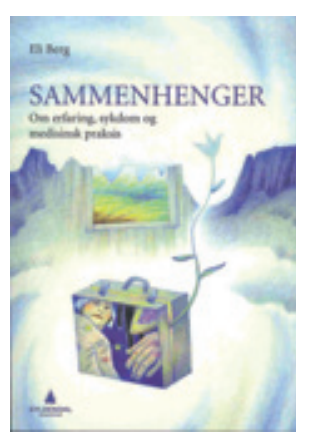

Dette er bok nummer to hvor forfatteren forteller om sin oppdagelse: at det er en sammenheng mellom allmennmedisinske pasienters uklare og residiverende somatiske symptomer og tidlige tilknytningsforhold, foreldrerelasjoner for øvrig, mishandling, neglisjering og andre traumer i barndom og oppvekst, personlighet og problematiske, nåværende relasjoner. Hun oppdaget også at hvis pasienter med uklare, residiverende somatiske symptomer fikk tid nok til å fortelle sin historie, ble de klart bedre. Hun drar også til hjemstedet med en pasient som klarer å gjenoppleve mange av sine barndoms grusomheter uten å bli retraumatisert, men som heller blir klart bedre. Forfatteren formidler også hva pasienter som er blitt hjulpet med å fortelle sin historie, mener er et godt lege-pasient-forhold, noe som stem- mer helt med hva vi lærer medisinstudentene fra første semester. Hun gjennomgår også noen filosofers uttalelser om nære kontaktforhold. Til slutt refererer hun litt nyere litteratur om mekanismene for sammenhengen mellom traumer, stress og sykelighet.

Forfatteren, som har vært allmennmedisiner og nå er førsteamanuensis, skriver engasjert om sine oppdagelser og pasientkontakter. Problemet er at hun fremstiller dette som nye oppdagelser i faget. Men dette er kunnskap hun skulle hatt med seg fra medisinstudiet og utdanningen til allmennmedisiner. Alt hun oppdager, er for lengst etablert kunnskap i psykologi, psykoterapi, psykoanalyse, psykosomatisk medisin, psykobiologi, psykiatri og medisinske atferdsfag. Dessverre mangler boken i stor grad referanser til denne litteraturen.

Men forfatteren har helt rett: Man tar fortsatt ikke godt nok konsekvensen av denne viktige kunnskapen når man organiserer legenes arbeid. Med praktiske eksempler dokumenterer hun hvilke positive resultater fastlegene kan oppnå, om de tar kunnskapen om sammenhengen mellom tidligere og nåværende følelsesmessige opplevelser og sykdom, på alvor.

En grunnleggende svakhet er at forfatteren helt hopper over våre empiriske kunnskaper om emnet fra medisinsk psykologi, psykosomatisk medisin og psykoterapi. Og det til tross for at hun selv brukte en psykolog som medhjelper. I stedet bruker hun en rekke filosofers formuleringer til å forklare og validere de kunnskapene vi har fra klinisk erfaring og forskning vedrørende lege-pasient-forholdet. Men når hun hos filosofene finner formuleringer som kan passe med den kliniske erfaringen og empiriske kunnskapen, er det filosofens funderinger som valideres og ikke omvendt, slik vi kan få inntrykk av.

Boken kan leses av fastleger som en påminnelse om betydningen av å høre pasienten fortelle sin historie. Når jeg nøler med å anbefale den til studenter og unge kolleger, er det fordi jeg er redd de kan oppfatte tilnærmingen til pasienter som noe eksotisk og sjeldent som forfatteren alene har oppdaget, og som de derfor ikke behøver å bry seg så mye om, hvis de ikke vil.

\section{Per Vaglum}

Avdeling for medisinske atferdsfag Universitetet i Oslo 